\title{
MEMBANGUN MAIL SERVER BERBASIS LINUX MENGGUNAKAN POSTFIX ADMIN DI PT. KEMUNING TELEVISI
}

\author{
Ali Akbar Rismayadi ${ }^{1}$, Salman Topiq ${ }^{2}$, Rinto Nurtantho ${ }^{3}$ \\ 1 Universitas Adhirajasa Reswara Sanjaya \\ e-mail: ali@ars.ac.id \\ ${ }^{2}$ Universitas Adhirajasa Reswara Sanjaya \\ e-mail: salmantopiq@gmail.com \\ 3Universitas Adhirajasa Reswara Sanjaya \\ e-mail: rintonurtantho@ymail.com
}

\begin{abstract}
Abstrak
Prosedur pemulihan kata sandi akun e-mail Gmail dan Yahoo dianggap menyulitkan bagi karyawan Kemuning TV, dikarenakan tidak mencantumkan nomor telepon ataupun akun lainnya. Selain itu tidak adanya standarisasi penamaan akun karyawan membuat pertanyaan apakah benar akun yang bersangkutan merupakan karyawan perusahaan. Karena itu dibutuhkan mail server tersendiri untuk mengelola akun e-mail perusahaan. Dibuatlah mail server berbasis linux menggunakan postfix admin sebagai antarmuka web untuk pengelolaan akun. Mail server ini dibangun pada VPS linux ubuntu. Postfix dan dovecot adalah aplikasi open source yang penting dalam mengirim dan menerima e-mail. Kedua aplikasi tersebut mendukung TLS untuk mengenkripsi komunikasi e-mail dan dapat diintegrasikan dengan anti virus dan anti spam seperti ClamAV dan SpamAssassin. Antarmuka web postfix admin dan webmail telah didukung oleh HTTPS. Dengan mail server menggunakan postfix admin maka pengelolaan akun e-mail oleh staf IT menjadi sangat mudah. Karyawan pun tinggal membuka webmail ataupun aplikasi e-mail smartphone untuk menerima dan mengirim e-mail tanpa batasan waktu. Sistem corporate e-mail juga meningkatkan citra, legalitas, publisitas dan profesionalitas Kemuning TV bagi pemirsa, pemerintah daerah dan pelaku bisnis di Kabupatan Karawang.
\end{abstract}

Kata Kunci: E-mail, Mail Server, Postfix Admin, Squirrelmail

\begin{abstract}
The password recovery procedure for Gmail and Yahoo e-mail accounts is considered difficult for Kemuning TV employees, because they do not include phone numbers or other accounts. Besides that there is no standardization of naming employee accounts which making questions is it true that e-mail account is really a company employee. Therefore a separate mail server is needed to manage the company e-mail account. Linux-based mail server is created using postfix admin as a web interface for account management. This mail server is built on ubuntu linux VPS. Postfix and dovecot are important open source applications for sending and receiving e-mail. Both applications support TLS to encrypt e-mail communication and can be integrated with anti-virus and anti-spam such as ClamAV and SpamAssassin. The postfix admin web interface and webmail are supported by HTTPS. With the mail server using postfix admin managing electronic mail accounts by IT staff now is very easy. The employee just needs to open webmail or smartphone e-mail application to receive and send electronic mail without time limits. Corporate e-mail also enhances brands, legality, publicity and professionalism of Kemuning TV for viewers, local governments and business people in Kabupaten Karawang.
\end{abstract}

Keywords: E-mail, Mail Server, Postfix Admin, Squirrelmail 


\section{Pendahuluan}

Teknologi informasi khususnya jaringan komputer menjadi pilihan yang tepat baik bagi perusahaan maupun personal untuk menyediakan informasi dan data secara cepat dan terbaru (Kusmaya, 2016).

Informasi berupa data akan mengalir dari satu komputer ke komputer lainnya atau dari satu komputer ke perangkat lain, sehingga masing-masing komputer dan perangkat yang terhubung bisa saling bertukar informasi dan data ataupun berbagi sumber daya, seperti berbagi disk, aplikasi dan lainlain (Primartha, 2019).

Penyampaikan informasi atau kabar yang dulunya menggunakan media surat melalui kantor pos saat ini sudah ada beralih ke e-mail (elektronic mail) yang dalam padanan bahasa indonesia disebut surat elektronik atau pos elektronik. Saat ini banyak penyedia layanan surat elektronik yang bisa digunakan secara gratis, seperti layanan e-mail google, yahoo ataupun microsoft. Banyak perusahaan-perusahaan milik pemerintah atau instansi swasta menggunakan layanan surat elektronik untuk berinteraksi dengan masyarakat dan juga untuk komunikasi internal (Kusmaya, 2016).

Mail server juga dapat melayani komunikasi dan transfer data secara offline melalui jaringan lokal (Desmira et al., 2017).

Mail server merupakan salah satu fungsi server yang paling banyak digunakan di suatu institusi, lembaga atau perusahaan. Hal ini mengingat fungsi surat elektronik yang bisa mengurangi biaya kertas, lebih cepat dan lebih efisien dibandingkan komunikasi manual dan dapat menggunakan lampiran sebagai pelengkap dan dokument tambahan terkait isi surat elektronik (Hakim Zainul, Hanafri Reza M., 2015).

Sistem mail server dapat dibangun pada sistem operasi linux yang terkenal gratis, handal dan stabil menangani sebagai fungsi mail server dengan menggunakan aplikasi MTA Postfix (Chandra, 2018).

Server merupakan kombinasi dari perangkat keras dan perangkat lunak yang dirancang untuk menyediakan layanan untuk client pada sebuah jaringan computer dan digunakan untuk menjalankan perangkat lunak administratif yang mengontrol akses terhadap jaringan dan sumber daya yang terdapat didalamnya (Dasril et al., 2017) .

Proxmox merupakan virtualisasi berbasis Debian (64 bit) yang mengusung OpenVZ dan KVM, memungkinkan untuk melakukan manajemen terpusat dari banyak server fisik.
Sebuah Proxmox terdiri dari minimal satu master dan beberapa node (minimal satu master dan satu node). Proxmox merupakan salah satu software virtualisasi yang berbasiskan open source (Purbo, 2012).

Para karyawan dan kontributor PT. Kemuning Televisi pun menggunakan layanan surat elektronik gratis tersebut. Dengan tidak adanya standar penamaan akun, maka para karyawan bebas memilih nama akunnya sendiri. Terkadang para karyawan sering lupa kata sandi akun, nomor telepon pemulihan sehingga mengalami kesulitan untuk masuk ke dalam akun surat elektronik mereka. Akibatnya selain harus membuat akun baru, banyak informasi serta data perusahaan yang harus dikirim ulang. Oleh karena itu pimpinan PT. Kemuning Televisi membuat standarisasi akun surat elektronik, baik untuk para karyawan, kontributor dan departemen yang ada.

Berdasarkan kebutuhan tersebut, maka PT. Kemuning Televisi, memerlukan sistem e-mail private yaitu sistem surat elektronik yang di bangun sendiri pada suatu instansi atau suatu perusahaan. Sistem e-mail private pada satu instansi atau perusahaan umumnya dikenal juga dengan istilah corporate e-mail. Sistem surat elektronik kategori ini sangat perlu digunakan sebagai penanda legalitas bahwa pengirim surat elektronik merupakan salah satu karyawan yang ada pada perusahaan tersebut (Barovih, 2015)

Dengan layanan corporate e-mail, PT. Kemuning Televisi selain dapat memudahkan komunikasi antar karyawan, juga dapat dipakai sebagai penyimpanan data sementara, walau hanya mempunyai kapasitas terbatas. Kemudian terdapat standarisasi penamaan akun, sesuai dengan departemen dan nama karyawan yang ada diperusahaan. Lalu pengelolaan akun lebih mudah. Selain itu dari sisi komersial, dapat meningkatkan kepercayaan rekan usaha dan media terhadap perusahaan.

\section{Metode Penelitian}

Metode penelitian yang penulis lakukan adalah bersifat kualitatif untuk pemecahan masalah, dan metode yang digunakan untuk menunjang dari penelitian adalah :

\section{Pengumpulan Data}

1. Observasi melakukan observasi proses pembuatan akun, pengiriman dan penerimaan surat elektronik para karyawan PT. Kemuning Televisi yang telah berjalan kemudian menganalisanya 
agar mendapat gambaran bagaimana nantinya pembuatan mail server dapat berjalan sesuai yang diharapkan dalam memenuhi segala kebutuhan serta sesuai standar yang ditetapkan pimpinan PT. Kemuning Televisi.

2. Wawancara melakukan tanya jawab langsung untuk mengetahui sistem surat elektronik berjalan yang ada secara langsung dari staf IT dan juga terhadap karyawan lain serta kontributor lapangan PT. Kemuning Televisi.

3. Studi Pustaka melakukan studi kepustakaan yaitu dengan mengumpulkan datadata teoritis dan mempelajari buku-buku, jurnal dan artikel baik di internet maupun perpustakaan dengan maksud untuk mendapatkan teori-teori dan bahan-bahan yang berkaitan dengan masalah tersebut diatas.

\section{Metode Pengembangan Aplikasi \\ a. Analisa Kebutuhan}

melakukan berbagai analisa kebutuhan sebagai pendukung dalam membangun mail server. Kebutuhan untuk membangun mail server meliputi kebutuhan perangkat keras, perangkat lunak dan arsitektur jaringan. Untuk kebutuhan perangkat keras, penulis memanfaatkan virtual private server yang telah digunakan sebagai web server.

Spesifikasi VPS yang telah digunakan adalah dual core CPU yang berkecepatan 2.4Ghz, memori 1Gb, kapasitas penyimpanan harddisk sebesar 20Gb dan kuota bandwidth sebesar 1000Gb telah penulis anggap cukup untuk menjalankan sebuah mail server.

VPS menggunakan operasi sistem Linux Ubuntu Server 16.04 Long Term Support. Untuk kebutuhan perangkat lunak dapat dilihat dalam tabel berikut:
Tabel 1. Perangkat Lunak

\begin{tabular}{|c|c|}
\hline Nama & Fungsi \\
\hline Postfix & SMTP server \\
\hline Dovecot & Pop/Imap server \\
\hline ClamAV & Anti virus \\
\hline SpamAssasin & Anti spam \\
\hline Squirrelmail & Webmail \\
\hline Postfix admin & Manajemen user \\
\hline
\end{tabular}

\section{b. Desain}

Membangun mail server berdampingan dengan webserver pada VPS. Semua komponen mail server haruslah dapat melakukan fungsi menangani semua surat elektronik yang masuk dan keluar, tempat penyimpanan sementara, menyaring surat elektronik dari spam dan virus dan sebagai antarmuka web bagi administrator dan pemilik akun.

\section{c. Testing}

Tahapan dimana mail server akan diuji sesuai dengan tujuan awal pembuatan. Tahapan awal pengujian mail server dilakukan secara online melalui situs https://mxtoolbox.com/NetworkTools.aspx, untuk mengetahui koneksi dan berbagai konfigurasi mail server. Kemudian pengujian mengelola akun menggunakan Postfix Admin, mengirim dan menerima surat elektronik menggunakan antarmuka web Squirrelmail ataupun aplikasi komputer seperti Mozilla Thunderbird atau Microsoft Outlook. Serta pengujian keamanan mail server dalam menyaring spam, virus serta lampiran yang berbahaya.

\section{Hasil dan Pembahasan}

Dari penelitian yang telah dilakukan didapat hasil untuk menambahkan topologi Client/Server pada jaringan komputer yang telah ada. Menurut (Sukaridhoto, 2014), server adalah aplikasi yang memberikan pelayanan kepada user internet. Client adalah yang meminta pelayanan. Aplikasi bisa memiliki bagian server dan bagian client, dimana dapat berjalan secara bersamaan dalam satu sistem. Server merupakan progam yang dapat menerima permintaan, melakukan pelayanan yang diminta, kemudian mengembalikan sebagai reply. 
Server dapat melayani multi request bersamaan.

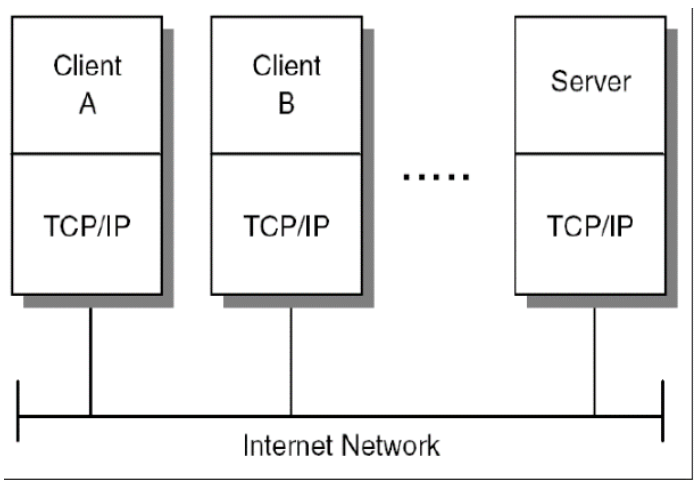

Gambar 1. Model Client/Server

Server bekerja dengan cara menunggu request pada port yang sudah terdaftar, sehingga client dapat dengan mudah mengirimkan data ke port pada server.

\subsection{Topologi Usulan}

Topologi jaringan Client/Server usulan disamping topologi hybrid yang telah berjalan dapat dilihat pada gambar 2. berikut ini :

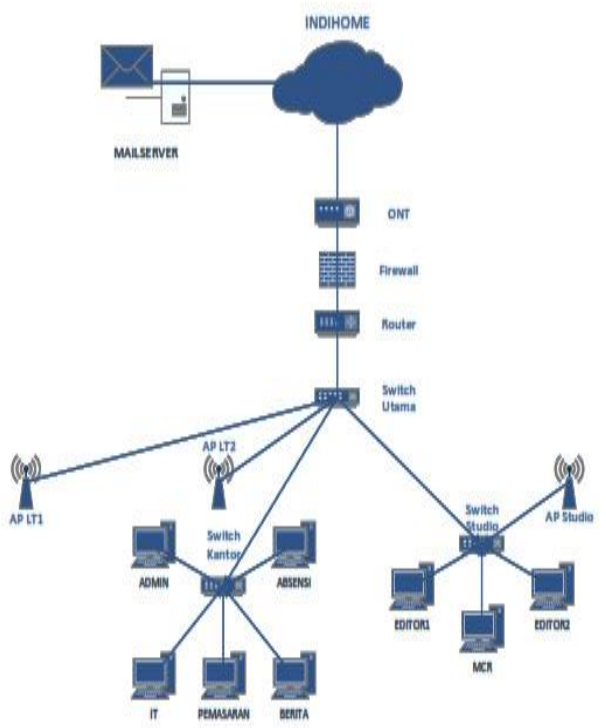

Gambar 2. Topologi Hybrid usulan Sumber: Hasil Penelitian

\subsection{Keamanan Jaringan}

Untuk melindungi mail server, maka keamanan jaringan selain menggunakan firewall, penulis mengunakan langkahlangkah sebagai berikut: a. Menggunakan SpamAssasin sebagai aplikasi pengidentifikasi spam dan mencegahnya tidak masuk ke kotak surat pengguna.

b. Menggunakan ClamAV sebagai aplikasi anti virus yang mengidentifikasi apakah surat elektronik terdapat virus, kemudian menghapusnya sebelum masuk ke kotak surat pengguna.

c. Menggunakan protokol HTTPS agar tidak terjadi penyadapan data ketika masuk pada antarmuka Postfix Admin dan Squirremail.

d. Mengaktifkan akses TLS pada postfix, untuk mengenkripsi data surat elektronik agar terjamin keamanannya. Port yang digunakanpun berbeda dengan port standar protokol IMAP dan SMTP, yaitu port 993 untuk encrypted IMAP dan port 465 untuk encrypted SMTP.

e. Membatasi jaringan atau IP Address yang diijinkan untuk mengirim surat elektronik atau disebut closed relay SMTP. Agar tidak dimanfaatkan oleh pihak yang tidak bertanggung jawab.

f. Mengaktifkan konfigurasi Sender Policy Framework pada konfigurasi Postfix dan DNS Server.

g. Langkah optional dengan menggunakan Domain Keys Identified Mail.

\subsection{Rancangan Aplikasi}

a. Menambahkan MX Records domain kemuning.tv pada konfigurasi DNS server VPS. Semua surat elektronik yang dialamatkan ke domain kemuning.tv akan diarahkan ke host www.kemuning.tv dengan prioritas tertinggi.

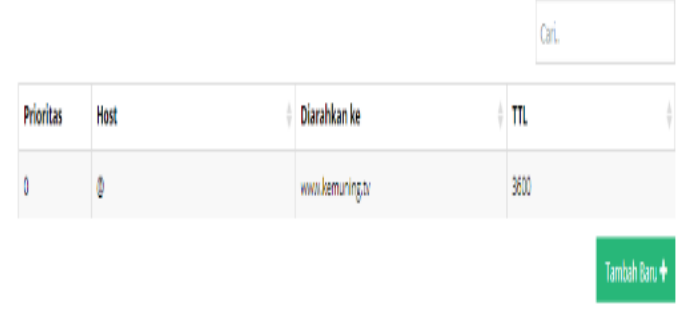

Gambar 3. Konfigurasi $M X$ Records

b. Menginstal Postfix dengan perintah aptget install postfix. Nanti muncul pilihan general mail configuration, pilih Internet Site, karena mail server akan terhubung langsung dengan internet. Opsi berikutnya adalah system mail name, diisi dengan hostname www.kemuning.tv sesuai dengan MX Records diatas. Setelah proses instalasi selesai, maka didalam folder letc/postfix, terdapat dua 
berkas konfigurasi utama postfix, yaitu main.cf dan master.cf. Kemudian jalankan dengan perintah /etc/init.d/postfix start. Lalu telnet ke localhost port 25, jika berjalan maka telnet akan masuk pada service postfix.

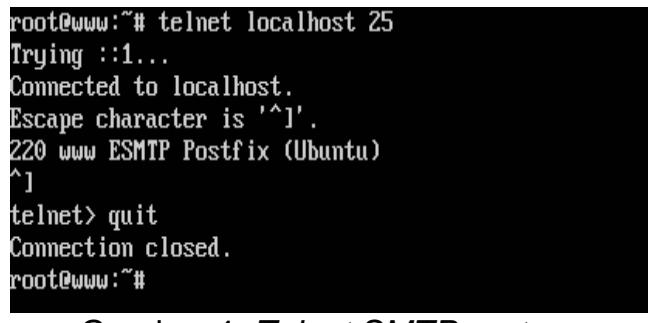

Gambar 4. Telnet SMTP port

c. Menginstal Dovecot dengan perintah aptget install dovecot-core dovecot-imapd. Folder utama konfigurasi dovecot terletak di /etc/dovecot/conf.d/. Jalankan dengan perintah /etc/init.d/dovecot sart. Lalu telnet ke localhost port 143, jika berjalan maka telnet akan masuk pada service dovecot.

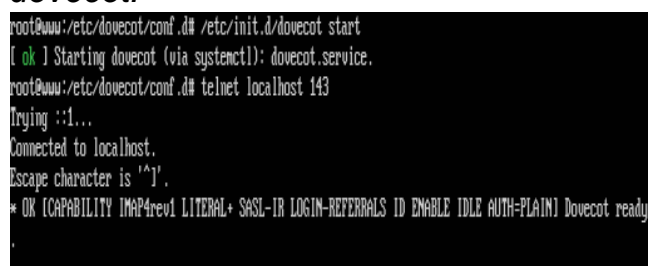

Gambar 5. Telnet IMAP port

Sumber: VPS Kemuning TV

d. Menginstal Squirrelmail dengan perintah apt-get install squirrelmail. Kemudian salin file /etc/squirrelmail/apache.conf ke folder/etc/apache2/sites-

available/squirrelmail.conf . Kemudian edit file/etc/apache2/sitesavailable/squirrelmail.conf sesuaikan seperti gambar dibawah ini.

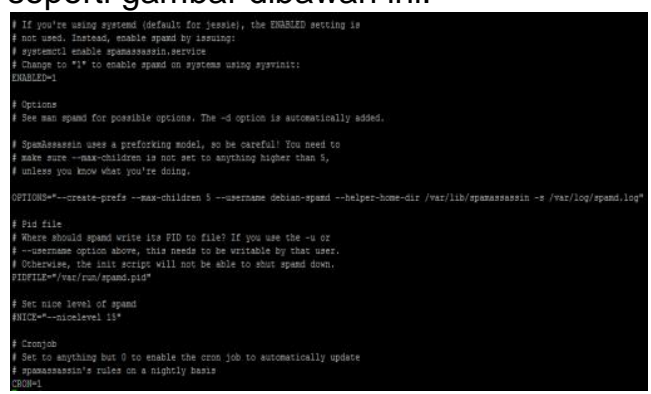

Gambar 6. Konfigurasi Squirrelmail.conf Sumber: VPS Kemuning TV

e. Menginstal Postfix dengan perintah aptget install postfixadmin. Nanti muncul pilihan untuk membuat MySQL database, tabel dan kata sandinya. Kemudian integrasikan postfix admin dengan postfix, dengan menambahkan konfigurasi dibawah ini ke dalam file letc/postfix/main.cf.

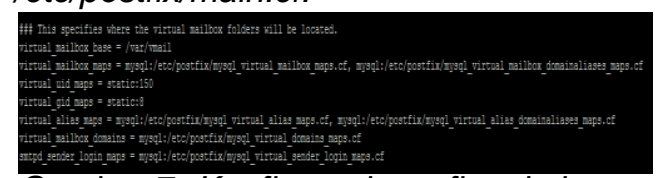

Gambar 7. Konfigurasi postfix admin

Sumber: VPS Kemuning TV

f. Menginstal ClamSMTP dengan perintah apt-get install clamsmtp. Setelah terinstal, lalu edit file letc/clamsmtpd.conf rubah baris User: clamsmtp menjadi User: clamav dan tambahkan pada baris terakhir Action: drop.

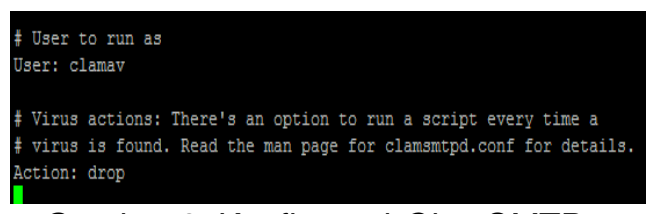

Gambar 8. Konfigurasi ClamSMTP

Sumber: VPS Kemuning TV

h. Menginstal SpamAssasin dengan perintah apt-get install spamassassin spamc. Kemudian edit file letc/default/spamassasin, rubah $E N A B L E D=0$ menjadi $E N A B L E D=1$ untuk mengaktifkan, $C R O N=0$ menjadi $C R O N=1$ untuk otomatis pembaharuan dan menambahkan username dan opsi $\log$.

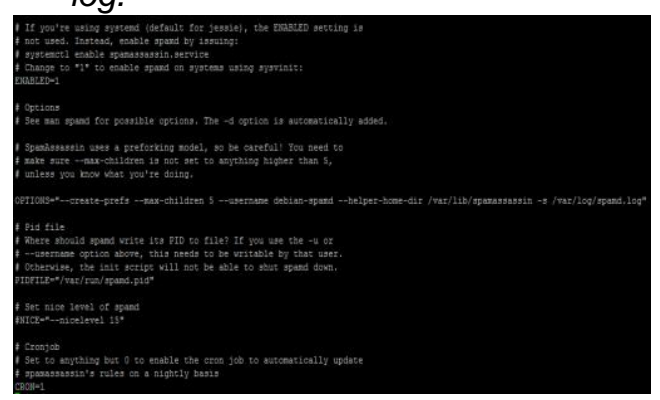

Gambar 9. Konfigurasi SpamAssasin Sumber: VPS Kemuning TV

\subsection{Hasil Rancangan}

Setelah itu dapat dilihat hasilnya dengan mencoba melakukan test SMTP server pada situs mxtoolbox.com. Pastikan hasil semuanya bertanda centang hijau, baik DNS, TLS, connection time dan closed open relay. Yang artinya SMTP server berjalan dengan baik. 


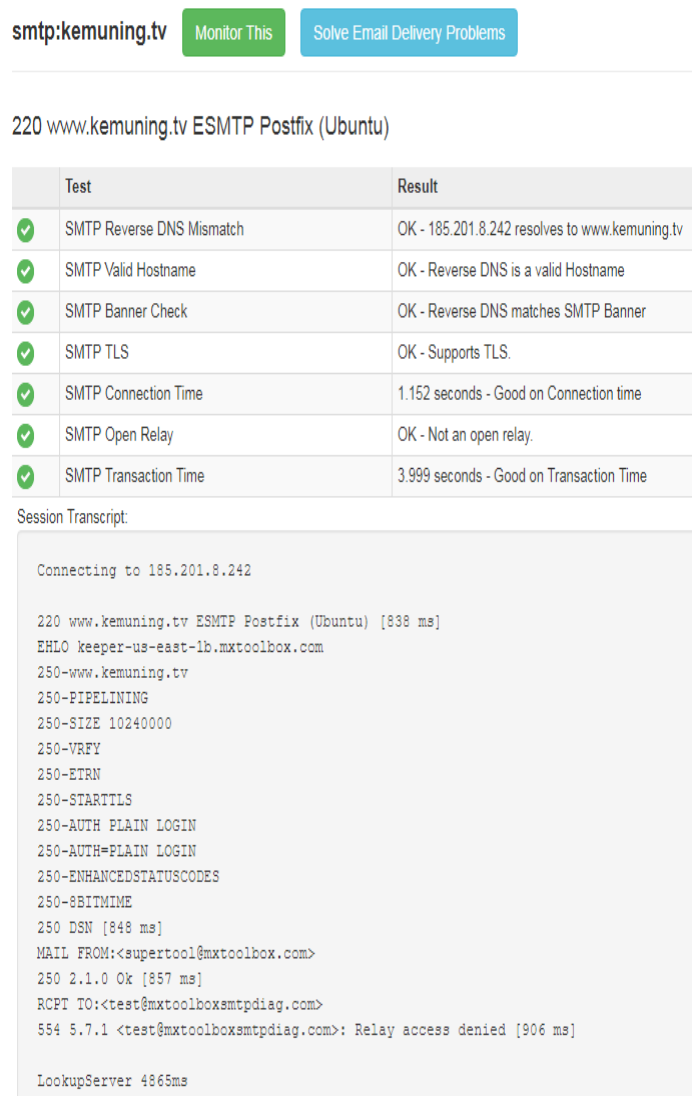

Gambar 10. SMTP server test

Penggunaan Postfix Admin adalah untuk mempermudah administrator jaringan dalam mengelola akun surat elektronik. Dalam hal ini penulis akan mencoba membuat akun baru.Bukalah www.kemuning.tv/postfixadmin lalu masuk menggunakan akun administrator postfix admin. Setelah masuk, lalu pilih add mailbox. Kemudian pada form tambah akun, isi username, password, full name, kemudian klik add mailbox.

\section{postfix.admin}

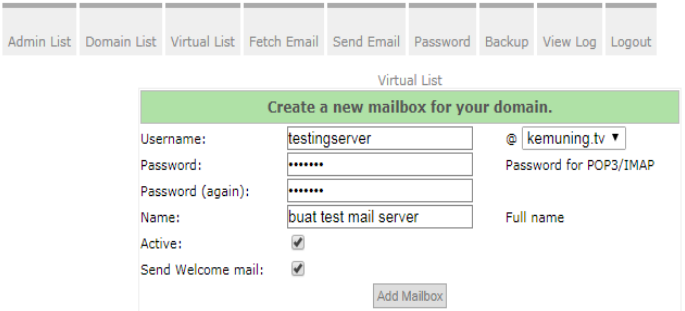

Gambar 11. Form tambah akun

Buka laman situs www.kemuning.tv/webmail lalu masukan nama akun dan kata sandi yang telah dibuat melalui Postfix Admin. Lalu coba untuk berkirim dan menerima surat elektronik.

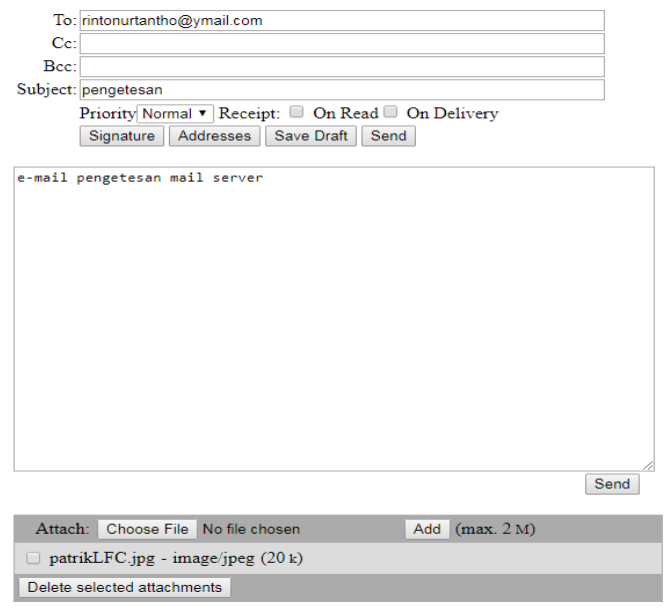

Gambar 12. Tampilan menulis surat

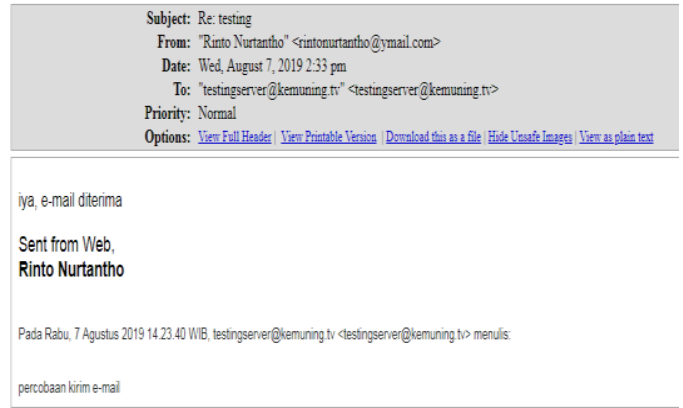

Gambar 13. Tampilan surat masuk

\section{Kesimpulan}

Dibangunnya mail server berbasis Linux menggunakan Postfix Admin mempermudah administrator mail server dalam mengelola akun surat elektronik. Penggunaan sender policy framework, domain keys identified mail, clamav dan spamassasin membuat mail server yang dibangun lebih aman dari gangguan virus dan spam dari pihak-pihak yang tidak bertanggung jawab.

Squirrelmail merupakan aplikasi webmail yang mudah digunakan, handal dan memiliki banyak fitur-fitur yang memperindah tampilan maupun keamanan. Selain itu, untuk mengakses akun pada komputer dapat juga menggunakan aplikasi e-mail seperti microsoft outlook dan mozilla thunderbird. Untuk smartphone dapat menggunakan aplikasi e-mail bawaan operasi sistemnya.

\section{Referensi}

Barovih, G. (2015). Analisis Perancangan dan Implementasi Mail System Pada PT. PLN (Persero) SBAM. Citec Journal, 2, 292-303. http://citec.amikom.ac.id/main/index.ph 
$\mathrm{p} /$ citec/article/view/56

Chandra, T. (2018). Membangun Mail Server Berbasis Postfix pada Sistem Operasi Linux. ILMIAH CORE IT, 80-87. http://domain.anda/squirrelmail

Dasril, Laswi, A. S., \& A, A. (2017). PERANCANGAN VIRTUAL PRIVATE SERVER MENGGUNAKAN PROXMOX PADA AMIK IBNU KHALDUN PALOPO. Prosiding SEMANTIK, 19-25. http://journal.uncp.ac.id/index.php/sem antik/article/view/987

Desmira, Sumarto, D., \& Yuliani, R. (2017). Rancang Bangun Mail Server Berbasis Squirrelmail Menggunakan MTA (Mail Transfer Agent) Pada PT. Teras Inti Media. Jurnal Prosisko, 4(ISSN : 2406773), 55-59. http://ejurnal.lppmunsera.org/index.php/PROS ISKO/article/view/392

Hakim Zainul, Hanafri Reza M., B. (2015). Perancangan Mail Server dengan Menggunakan Exchange Server Studi Kasus di STMIK Bina Sarana Global. Jurnal Sisfotek Global, 5(ISSN : 2088 1762), 10-13. https://stmikglobal.ac.id/journal/index.p $\mathrm{hp} /$ sisfotek/article/download/73/75

Kusmaya. (2016). Implementasi Mail Server Menggunakan Postfix. Jurnal Informasi, VIII(2), 49-69.

Primartha, R. (2019). Manajemen Jaringan Komputer Teori dan Praktik. Informatika Bandung.

Purbo, onno w. (2012). Membuat sendiri Cloud Computing server menggunakan open source. 116.

Sukaridhoto, S. (2014). Buku Jaringan Komputer I. In smkn4tpi.sch.id. http://www.smkn4tpi.sch.id/web/media library/files/c7b4c2832a88424d9917e 5f3e5bd64b9.pdf 